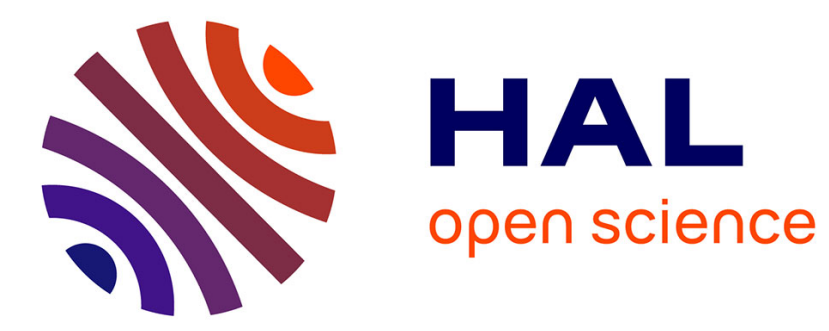

\title{
Chimpanzees of Gabon and Chimpanzees of Gombe: some comparative data on the diet
}

\author{
Claude Marcel Hladik
}

\section{To cite this version:}

Claude Marcel Hladik. Chimpanzees of Gabon and Chimpanzees of Gombe: some comparative data on the diet. T.H. CLUTTON-BROCK. Primate Ecology: Studies of Feeding and Ranging behaviour in Lemurs, Monkeys, and Apes, Academic Press, London, pp.81-501, 1977. hal-00561740

\section{HAL Id: hal-00561740 https://hal.science/hal-00561740}

Submitted on 16 Feb 2011

HAL is a multi-disciplinary open access archive for the deposit and dissemination of scientific research documents, whether they are published or not. The documents may come from teaching and research institutions in France or abroad, or from public or private research centers.
L'archive ouverte pluridisciplinaire HAL, est destinée au dépôt et à la diffusion de documents scientifiques de niveau recherche, publiés ou non, émanant des établissements d'enseignement et de recherche français ou étrangers, des laboratoires publics ou privés. 
HLADIK C.M. (1977) - Chimpanzees of Gabon and Chimpanzees of Gombe : some comparative data on the diet. In : T.H. CLUTTON-BROCK (Ed.) Primate Ecology: Studies of Feeding and Ranging behaviour in Lemurs, Monkeys, and Apes. Academic Press, London : 481-501.

\section{Chimpanzees of Gabon and Chimpanzees of Gombe: some Comparative Data on the Diet}

\section{M. HLADIK}

Laboratoire d'Ecologie et Primatologie du CNRS, Muséum National d'Histoire Naturelle, Brunoy, France

Introduction

2. Methods.

2.1. Comparison of study areas

2.2. Field methods

2.3. Observation sample

3. Comparative aspects of feeding behaviour

3.1. Daily variation in food intake

3.2. Feeding techniques and traditions

4. Variation in feeding and ranging behaviour

4.1. Seasonal variation

4.2. Annual food intake

4.3. Ranging patterns

5. Food composition

5.1. Variability among food categories

5.2. Protein intake

5.3. Mineral intake

5.4. Secondary compounds

6. Conclusion

7. Summary

Acknowledgements

\section{INTRODUCTION}

The feeding behaviour and diet of chimpanzees in Gabon (Pan troglodytes toglodytes), was the subject of a one-year field study in 1971-72 (Hladik, 


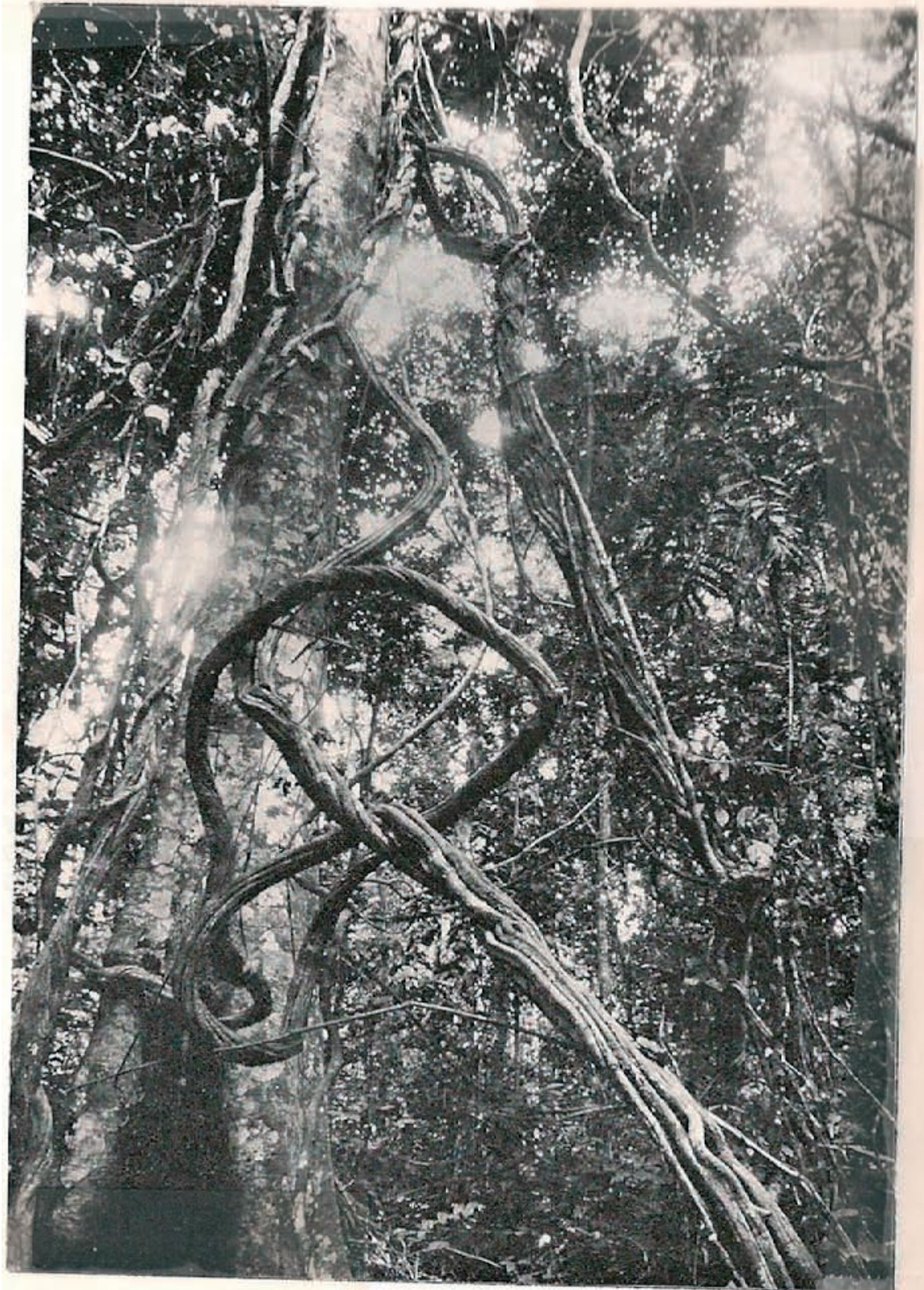

Frc. 1. Inside the rain forest at Ipassa.
16. PAN TROCIODYTIS TROGLODYTS AND P. I. SCHWEINEURTHII A83

1973). A parallel study of feeding behaviour on the well known population of Pan troglodytes schweinfurthii in the Gombe National Park, was carried out in 1972-73 (Wrangham, 1975 and this volume). Unfortunately, the scope of the comparison of these two studies is limited by the small amount of information concerning diet (quantification and composition) available for the latter population.

\section{METHODS}

\subsection{Comparison of Study Areas}

The Gabon study was carried out at the CNRS field station of Ipassa $(500 \mathrm{~m})$, mainly on a 2-km-long island in the Ivindo river. Vegetation diversity in the study area is very high and over 900 plant species have been determined and listed (Hladik and Hallé, 1973). Many lianas (Fig. 1) play an important part in the production of this forest (A. Hladik, 1974), especially in fruit production. The chimpanzee population consisted of eight subadults introduced into the island from the nearby forest. The chimpanzees were well habituated and the observer could usually stand among the group when recording. Bananas were provided at an artificial feeding area and, except during the minor dry season (when the fruits were very abundant), the animals obtained about $30 \%$ of their food from this. The observations were resumed in the 1975 minor dry season and little food was provided, the animals feeding on natural fruits, particularly those of Irvingia gabonensis.

In contrast, the habitat at Gombe is drier and more mountainous (Goodall, 1965; Clutton-Brock, 1975a). It includes open woodland and grassland and the vegetation is less diverse (see Clutton-Brock, 1975a; Appendix II: at Gombe only nine species account for $50 \%$ of the tree population, while in the Ipassa forest, in a smaller sample, 15 species accounted for $50 \%$ of the tree population).

At Gombe, the chimpanzees obtained small amounts of bananas from the artificial feeding area (less than 20\% of their food, according to Wrangham), but were not fed during Wrangham's study.

\subsection{Field Methods}

Individual animals were observed from dawn to dusk and their food intake recorded using the methodology described in Chapter 11. As Table I shows, the amount of time spent feeding on different foods was not closely related to their abundance in the diet.

Food samples were collected in order to calculate the weight of the 


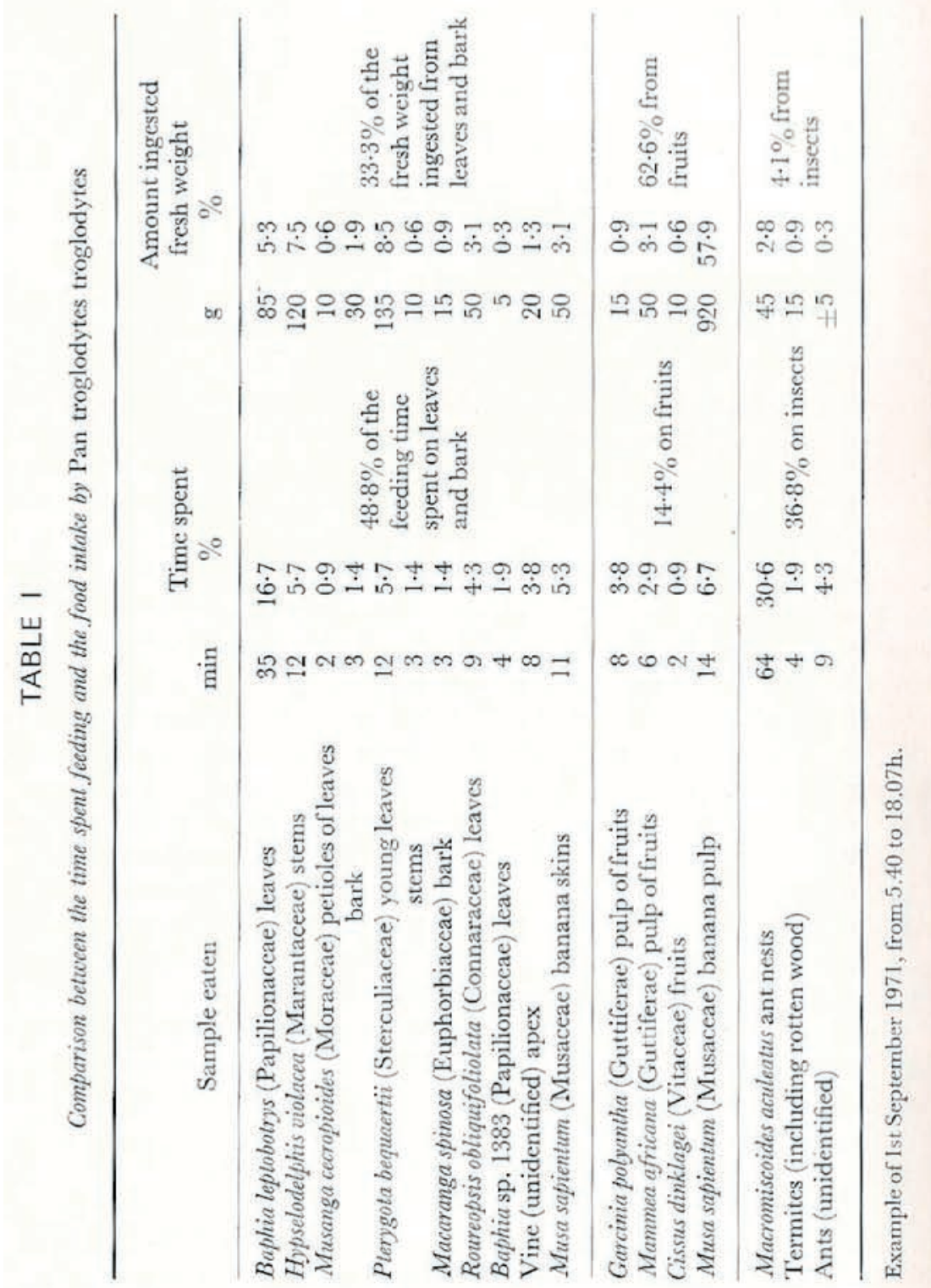

16. PAN TROGLODVTIS TROQLOOVTES AND P, $T$, SCHWFINFURTHII 486

food ingested by the chimpanzes (average tresh weight). They were preservect by trethes in alcohol or by drying in an electric oven (sec Appendix III this volume).

\subsection{Observation Sample}

In Gabon total observation time was 27090 minutes during the 1971-72 field study. The dots along the time-axis of Fig. 4 indicate the days during which continuous observations were made.

\section{COMPARATIVE ASPECTS OF FEEDING BEHAVIOUR}

\subsection{Daily Variation in Food Intake}

ahere they have been studied (Goodall, 1963, 1965; Reynolds and Reynolds, 1965; Suzuki, 1969; Jones and Sabater Pi, 1971) the chimpanzees at I passa were primarily frugivorous. During the (1971-72, 141 plant food types (plus 33 animal five mineral foods) were identified and a further 144 foods and five could not be identified. This accounting for sin suggests that the chimpanzees ate a volume) recorded that they ate 140 Gombe, where Wrangham (this volume) recorded that they ate food types during an observation sample twice as long as ours. This is supported by comparison of the average number of food typest, the per day: more than 20 at Ipassa versus 14.6 at Gombe. Tn contrast, the numbers of feeding bouts per day were similar in the two areas. Teleki (pers. comm.) suggested that the differences in the number of the selected between the two areas could be related to the differences in the age classes observed.

Although this may be a contributory factor, the greater number of dible species available in Gabon, must also be involved.

Dife of day (Fig. 2) and

Different foods tend to be eaten at different times of day (1ig a) and this pattern varies seasonally. During the minor dry season, fruts a be eaten at the beginning and at the end of the day, whe main period of eaten most during the middle of the day, following the main period of fruit-eating. In the rainy season, fruits are eaten throughout the day (generally because they are found in small amounts dispersecterno range) and leaf-eating shows a marked peak in the late afternoon. The species from which leaves and stems are eaten, are generally abundant and can be found easily in the different parts of the range, and the diumal rhythm in food choice is not a product of the occasional finding of different plant species. Wrangham (this volume, Fig. 8) found a 

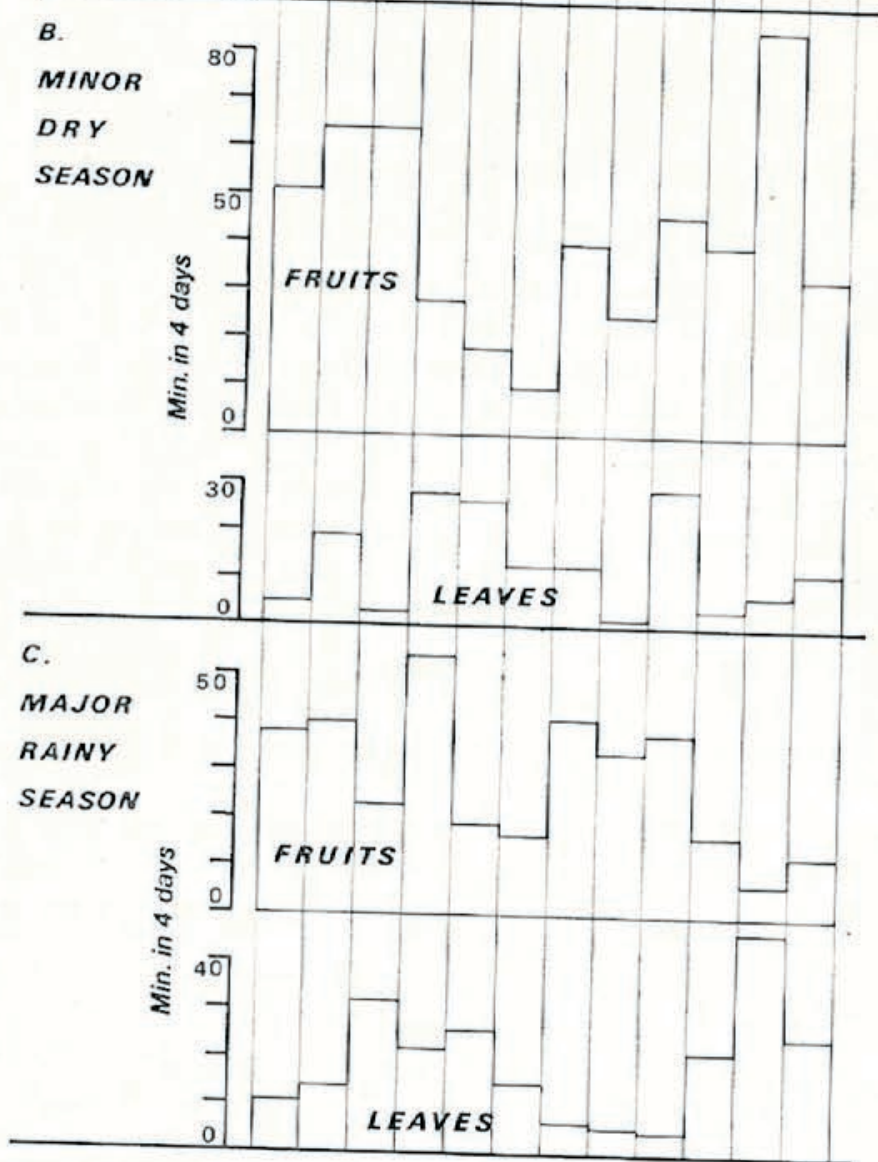

FIG. 2. Diurnal variation in time spent feeding on fruits and leaves by Pan troglodytes troglodytes, similar diflerence between the times when leaves and fruits were eaten at Gombc.

\subsection{Feeding Techniques and Traditions}

Some differences in feeding behaviour between the chimpanzees in Gabon and at Gombe are noticeable (Hladik, 1973) and the main points of comparison are related to tool-using.

Fecding on ants and termites is important to maintain the protein balance of the diet of the chimpanzee (see Section 5.2). Several ant species including Macromiscoïdes aculeatus, Oecophylla longinoda, Polyrhachis militaris, Paltothyreus tarsatus and Camponotus sp. are eaten, many of them after "fishing", a technique similar to that described for termite-eating at Gombe (Goodall, 1968), using a stem from which leaves have been stripped off with the mouth. At Gombe, Macrotermes bellicosus are caught with a grass stem (McGrew, 1974) while Macrotermes muellerii, although obviously edible, are not eaten by the chimpanzees in Gabon.

In contrast, feeding on scorpions was only observed in Gabon. At least one species, Opisthacanthus lecomtei, was killed by a rapid hand-slap before being chewed with some pieces of bark.

The bark from different trees and lianas is utilized by the chimpanzees in Gabon and chewed with any kind of animal food such as eggs and fledglings. At Gombe, some leaves are utilized for the same purpose. In addition, leaves that are never taken as food are also chewed to make "sponges" to extract the brain of prey (Teleki, 1973a) or to clean out the inside of hard-shelled fruits (Wrangham, this volume). The fibre wad although made by the chimpanzees in Gabon, was never actually made intentionally, as it was at Gombe. It was generally made from the stems of Hypselodelphis violacea, which was frequently eaten throughout the year (Fig. 3): the fibre, generally spat out, can be used as a sponge to drink water in a hole of a tree trunk.

Nut breaking with a tool was observed neither in Gabon nor at Gombe. In places where Panda oleosa and Coula edulis are eaten by the chimpanzees after breaking the hard shell of the nut (Struhsaker and Hunkeler, 1971; Rahm, 1971), there are obvious traces which have never been observed in Gabon, in spite of the abundance of Panda and Coula.

\section{VARIATION IN FEEDING AND RANGING BEHAVIOUR}

\subsection{Seasonal Variation}

Changes of the relative proportions of the fresh weight of fruits and leaves ingested (Fig. 4) can be related to the seasonal changes below. 


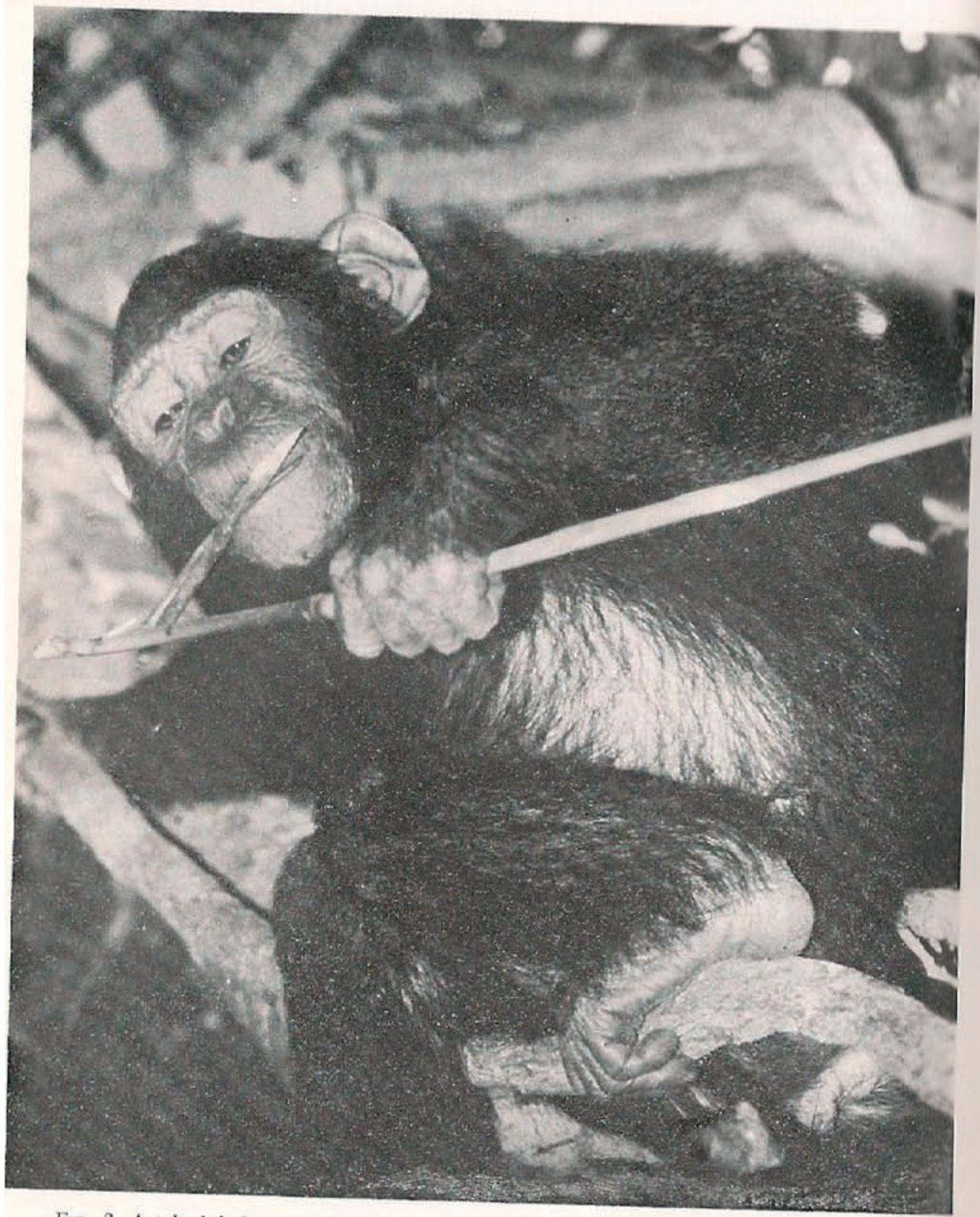

FTG. 3. A subadult female chimpanzee peeling, before chewing, the stem of a Marantaceac: Hypselodelphis violacea. 
accounts for the bulk of fecding time and, according to the high lipid content of Elaeis fruits, this must also be the bulk of the diet in terms of calories). In the rainy season, the leaves of two species (Plerocarpus tinctorius and Baphia capparidifolia) account for about $25 \%$ of the feeding time, while in Gabon at the same time, the leaves and stems of four species (Baphia leptobotrys, Hypselodelphis violacea, Pterygota bequaertii and Newbouldia laevis) account for $30 \%$ of the food intake with about 20 other species being eaten in small amount.

Many trees in the rain forest present an irregular phenological pattern (A. Hladik, 1977) and there are important differences of production between successive years (for example, the average production of fruits during the 1972 minor dry season was half that of the 1975 minor dry season). The resulting differences in the diet of the chimpanzees seem as important at Gombe as in Gabon. For instance, the fruits of Parinari curatellifolia were an important food resource in 1973 , at Gombe ( $41 \%$ of the feeding time during the fruiting period) but were not available in 1972. Similarly, in Gabon, the fruits of Irvingia gabonensis were extremely abundant in 1975 (more than 50\% of the food ingested in the records of February) but no fruiting occurred in 1972. Nevertheless, the general pattern of the diet was very similar in 1972 and 1975 .

\subsection{Annual Food Intake}

Figure 5 shows the average proportions of the different foods eaten by the chimpanzees in Gabon during one year, in terms of fresh weight: $68 \%$ of fruits; $28 \%$ of leaves and stems; $4 \%$ of animal food (insects and small prey) plus a very small amount of earth ingested.

Variations in the proportions of the different foods eaten each day is illustrated by the hatched columns indicating the maximum and the minimum observed. Fruits may form up to $90 \%$ of the daily intake and never less than $40 \%$, but most of the daily records include between 55 and $80 \%$ of fruits. The daily intake of animal food (essentially the ants, some termites, bird eggs and fledglings) varies between 2.5 and $6 \%$.

A comparison with Gombe is difficult in terms of food intake. The similar seasonal variation in feeding times cannot be applied to food intake, as shown in Section 2.2. The feeding time on leaves is shorter at Gombe than in Gabon and the proportion eaten may be smaller. On the other hand, the chimpanzees at Gombe eat small-sized game (Teleki, 1973a, 1975) and adult males spend a long time interacting and sharing the meat. The average consumption is around $10 \mathrm{~g}$ of meat per

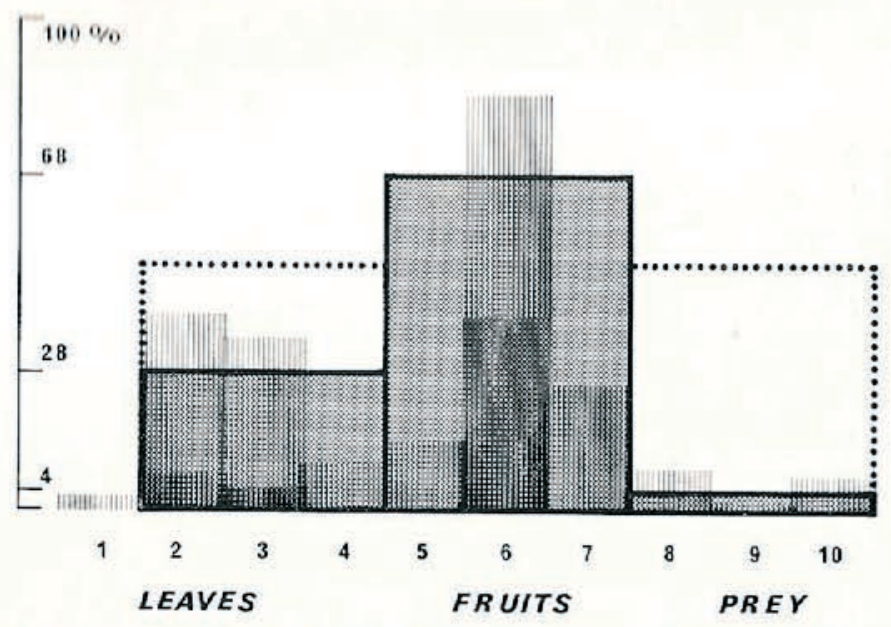

FIG. 5. Relative proportions of different food categories in the annual food intake of the chimpanzee in Gabon. The three shaded areas represent leaves $(28 \%)$, fruits $(68 \%)$ and chimpanzee in $\mathrm{Ga}$
animal foods $(4 \%)$.

Maxima and minima of daily food intake are shown by the hatched columns for earth (1); bark and stems (2); leaves, shoots and pith (3); flower buds and gums (4); immature fruits (5); ripe fruits (6); seeds and arils (7); small arthropods (8); large arthropods (9) and eggs and fledglings (10).

day per chimpanzee (Wrangham, pers. comm.) and, as a dietary protein complement, is of little importance (less than $0.5 \%$ of the diet) compared with the other types of animal foods, especially ants and termites.

\subsection{Ranging Patterns}

The distance travelled each day by the subadult female chimpanzees observed in Gabon was smaller than in Gombe, but on the small island where they have been observed, the physical limits may have restricted ranging patterns. The subgroupings and some other sociological factors of the history of the group (see C. M. Hladik, 1974) were partly related to the direction of travel, but movements were also influenced by the distribution of food.

Foraging was more frequent in the mid-canopy than on the ground. They had some preferred nesting places in tall trees $(40-50 \mathrm{~m})$ but none of these sites were ever occupied on two consecutive nights. 


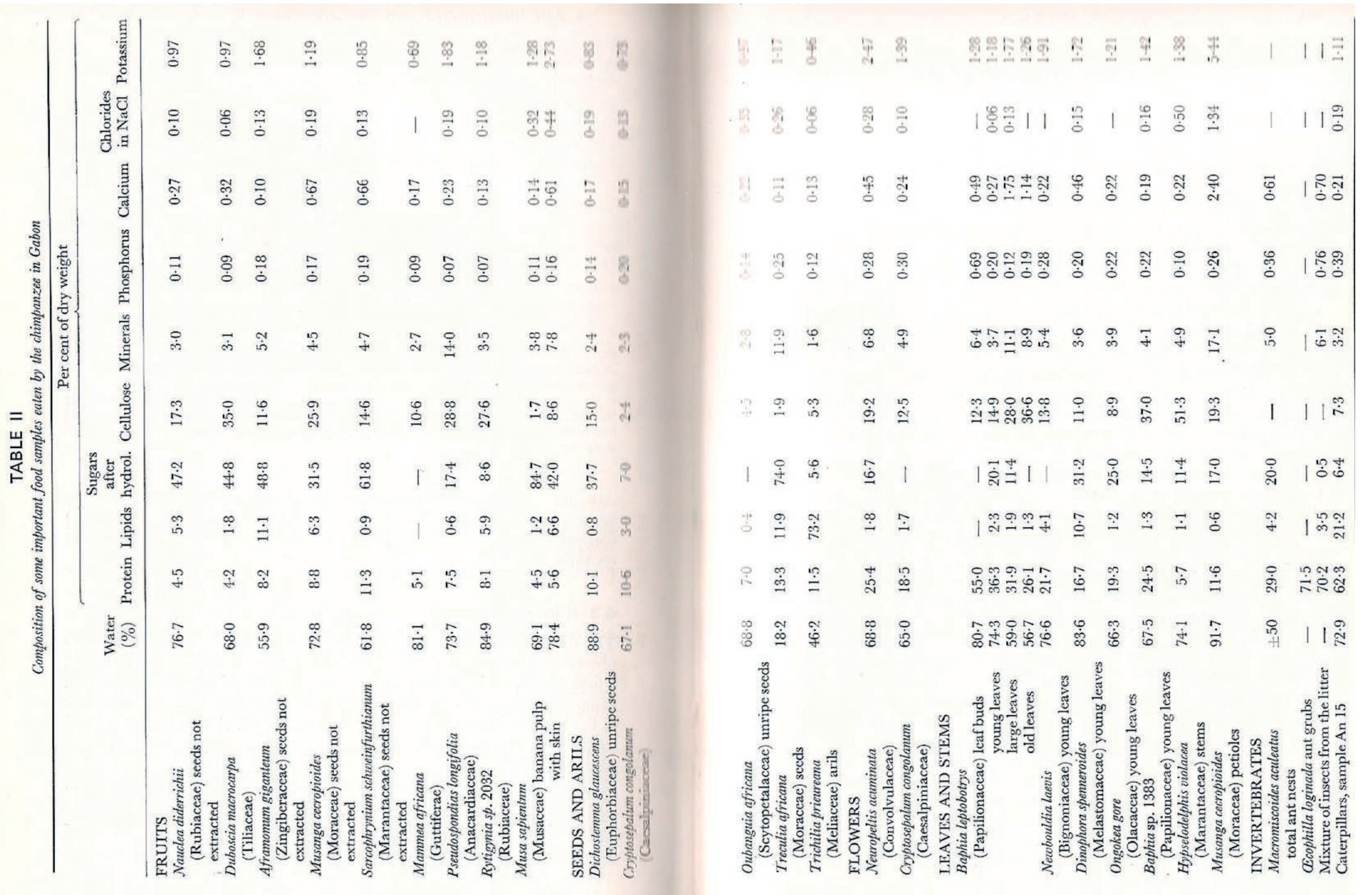




\section{FOOD COMPOSITION}

\subsection{Variability Among Food Categories}

The results of the analysis of food samples collected in Gabon (Table II) show the necessity of combining different food categories to obtain a balanced diet. Protein content of fruits is generally low: the sample average $(6.8 \%)$ is biased by the presence of fruits with small seeds (seeds are broken during the process of homogenization preceding analysis but usually found intact in the animals' faeces). Thus, in the pulp of most of the fruits, there is no more than $5 \%$ protein, which is insufficient to compensate for the loss of nitrogen of an adult chimpanzee. Seeds and arils are not rich enough (average 10.5\% protein) to complement the fruits and not available in sufficient amount. By contrast, leaves and stems are common and have a high protein content (average of 24.9\% for the ten samples). These, especially young leaves and shoots, may be eaten to complement fruit when invertebrates or the other animal prey cannot be obtained in sufficient quantity. A further ecological analysis of the relation of the food types with body mass and food availability is presented in G. M. Hladik (1977).

A rapid review of the other components listed in Table II indicates that only a mixture of the different food categories can give a balanced diet. Energy is found in the lipids of seeds and arils and in the glucids of the fruits (a technique of weak hydrolysis shows in terms of sugars what would be available as nutrients).

The proportion of different minerals varies between the different samples and only the combination of many plant species can result in a constant and balanced average. Phosphorus must be partly taken from animal foods while calcium is abundant in most leaf specimens. Some vegetable food, especially Hypselodelphis violacea stems and the petioles of Musanga cecropioides are extremcly poor in nutrients: their selection by the chimpanzee is presumably related to their exceptionally high mineral content.

\subsection{Protein Intake}

Why are invertebrates eaten by chimpanzees? Leaves, which can be collected and eaten in a relatively short time, yicld more protein than the small amounts of insects for which the chimpanzees foraged for $30-50 \%$ of the feeding time. One explanation may be the lower digestibility of plant protein when the proportion of fibre is high in the

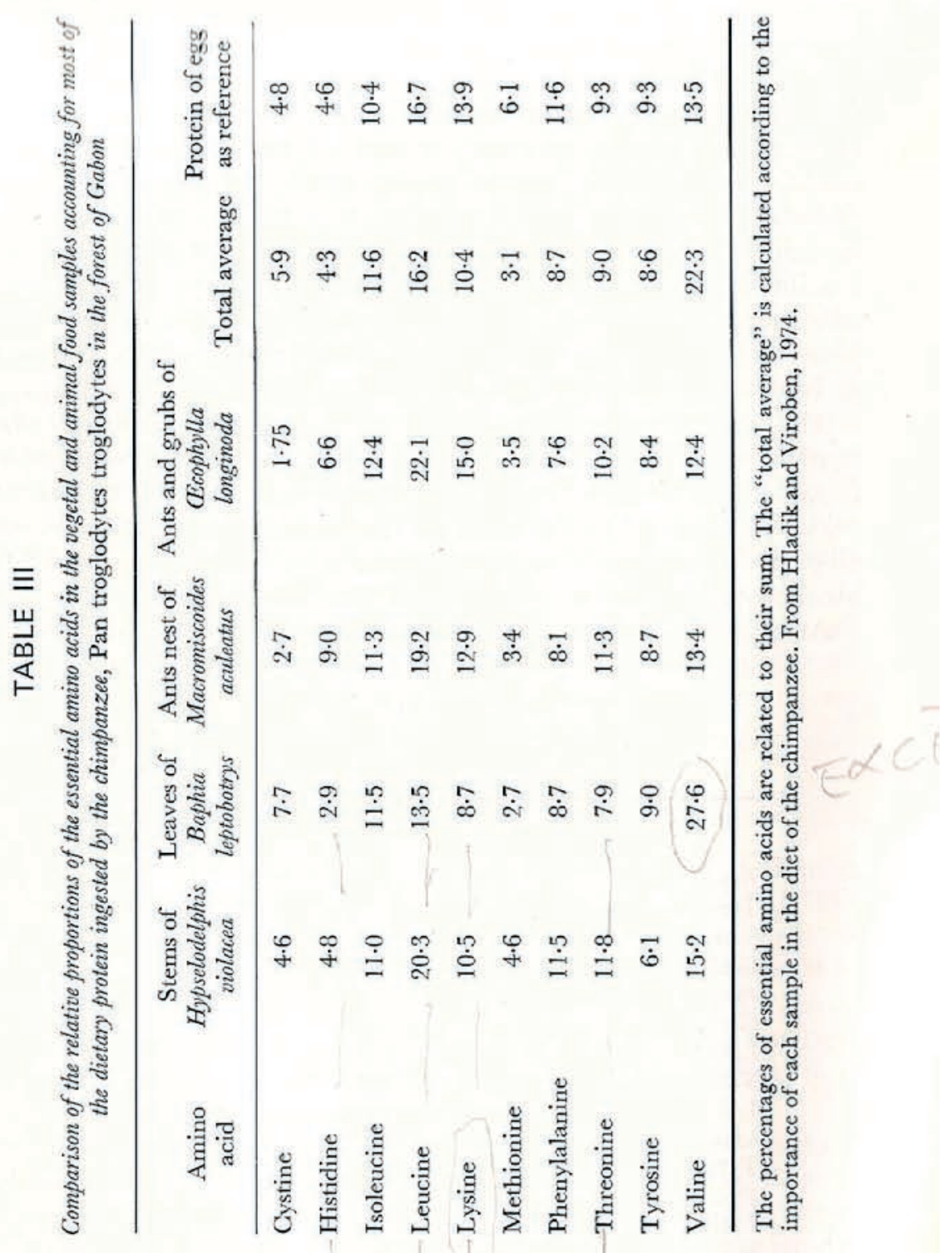


sample. In addition, insects may be eaten to supply essential amino acids, not present in sufficient amounts in plants. In Gabon, the chimpanzee utilizes relatively few plant species in large quantities during the rainy season, most of the leaves and stems are taken from four species (see Section 4.1) and two of them are eaten throughout the year (Hypselodelphis and Baphia leaves). It is noticeable that the amino acids of these two plants are partly complementary: the leaves of Baphia contain little leucine and threonine, while the shoots and stems of Hypselodelphis have a larger proportion of these amino acids in their protein (Table III). Nevertheless, the average proportions of histidine, leucine, lysine and threonine are low, due to an excess of valine. The ants eaten throughout the year (Macromiscoïdes and Oecophylla) compensate this lack of some essential amino acids. Conversely, feeding solely on insects would result in a lack of cystine (Hladik and Viroben, 1974).

The termites eaten at Gombe by the chimpanzees probably play the same role as the ants in Gabon and complement the proteins obtained from leaves. The composition of the protein fraction of Macrotermes bellicosus (Table IV) is fairly similar to that of the ants, with a percentage of phenylalanine and, to a lesser extent, of methionine, closer to the ideal proportions of egg protein used for comparison.

Among the termites of the above species, reproductives and soldiers

TABLE IV

Results of the analysis of the protein fraction of a sample of reproductive Macrotermes bellicosus collected at Gombe by R. W. Wrangham

\begin{tabular}{|c|c|c|}
\hline Protein & $\%$ of total protein & $\%$ of essential amino acids \\
\hline Aspartic acid & $7 \cdot 6$ & \\
\hline Threonine & 3.7 & $9 \cdot 1$ \\
\hline Serine & $3 \cdot 4$ & \\
\hline Glutamic acid & $10 \cdot 0$ & \\
\hline Proline & 4.8 & \\
\hline Glycine & $4 \cdot 8$ & \\
\hline Alanine & $5 \cdot 9$ & \\
\hline Valine & $5 \cdot 1$ & $12 \cdot 6$ \\
\hline Isoleucine & $3 \cdot 8$ & $9 \cdot 5$ \\
\hline Leucine & $6 \cdot 8$ & $16 \cdot 9$ \\
\hline Tyrosine & $6 \cdot 3$ & $15 \cdot 7$ \\
\hline Phenylalanine & $4 \cdot 1$ & $10 \cdot 1$ \\
\hline Lysine & $5 \cdot 6$ & $13 \cdot 9$ \\
\hline Histidine & $2 \cdot 7$ & $6 \cdot 6$ \\
\hline Arginine & $5 \cdot 1$ & \\
\hline Methionine & $1 \cdot 6$ & 4.0 \\
\hline Cystine & 0.7 & 1.6 \\
\hline
\end{tabular}

TABLE V

Comparison of protein content of diferent samples of Macrotermes bellicosus collected at Gombe by R. W. Wrangham

\begin{tabular}{lccc}
\hline & \multicolumn{3}{c}{ Per cent of dry weight } \\
& Protein $(\mathrm{N} \times 6 \cdot 25)$ & Lipicis & $\begin{array}{c}\text { Glucids after } \\
\text { hydrolysis }\end{array}$ \\
\cline { 2 - 4 } & $40 \cdot 6$ & $52 \cdot 8$ & - \\
Reproductives (eaten) & $58 \cdot 7$ & $<35$ & - \\
Soldiers (eaten) & $68 \cdot 4$ & $<25$ & $2 \cdot 1$ \\
Workers (not eaten) & &
\end{tabular}

but not workers are eaten by the chimpanzees. Curiously, analysis of the samples collected in Gombe by Wrangham, indicates that workers yield the maximum amount of protein (Table V). Selection of termites as food may be related mainly to the lipid content (detected by taste). Reproductives yield $52.8 \%$ lipids, while in the workers lipids account for less than $25 \%$. The unsaturated fatty acids found in animal lipids may be as important in the diet as the amino acids.

In Gabon, scorpions, of which the hepatopancreas and haemolymph are the main edible parts, are often eaten. Haemolymph is poor in fat but rich in free amino acids (M. Goyffon, pers. comm.) while glycogen and phospholipids are important components of the hepatopancreas. It is likely that the grouping of several of those components are responsible for the attractiveness of these arachnids.

\subsection{Mineral Intake}

Geophagy is common in chimpanzees, both in Gabon and at Gombe. Up to twice a day, animals ate pieces of earth of about 10 to $20 \mathrm{~g}$. The different earth samples are described in Hladik (1973). All of them are made of clay or other phyllitous materials with particules smaller than $2 \mu \mathrm{m}$ and most of them from earth that has been moulded by insects (very soft and with fine structure). The cylindric constructions ("chimneys") built by the larvae of Muansa clypealis (Homoptera) were often eaten by all the chimpanzees of the group.

The mineral content of these specimens of earth (Table VI) does not reveal any element in sufficient concentration to interact with mineral nutrition (Hladik and Gueguen, 1974). This was also the case of the earth samples eaten by the Presbytis species in Sri Lanka (see Hladik, this volume) and by other primates, mostly leaf-eaters, for which analytical data are available. The elements which might have some nutritive value for the chimpanzes occur at lower levels in the earth 
TABLE VI

Mineral content of different earth samples eaten by the chimfianzee, Pan troglody tes troglodytes. in Gabon

\begin{tabular}{|c|c|c|c|c|c|c|c|c|c|}
\hline & $\mathrm{P}$ & $\mathrm{Ca}$ & $\mathrm{Mg}$ & $\mathrm{K}$ & $\mathrm{Na}$ & $\mathrm{Fe}$ & $\mathrm{Zn}$ & $M_{n}$ & $\mathrm{Cu}$ \\
\hline $\begin{array}{l}\text { Earth from cylindric construc- } \\
\text { tion of Muansa clypealis larvae }\end{array}$ & 94 & 114 & 100 & 440 & 104 & 8600 & 21 & 18 & \\
\hline $\begin{array}{l}\text { Earth from mounds of } \\
\text { Macrotermes muellerii }\end{array}$ & 10 & 94 & - & 182 & 4 & - & - & - & \\
\hline $\begin{array}{l}\text { Earth sample collected near } \\
\text { the above mounds }\end{array}$ & 10 & 8 & - & 100 & 5 & - & - & - & \\
\hline $\begin{array}{l}\text { Earth from dripping part of } \\
\text { the nest of Procubitermes sp. }\end{array}$ & 490 & 448 & 70 & 540 & 95 & 33000 & 35 & 54 & 14 \\
\hline
\end{tabular}
the nest of Procubitermes sp.

The proportions of the different elements are in $10^{-6}$ (millionth of the dry weight). After Hladik and Gueguen, 1974.

samples than in many common food plants (Table VII). The low levels of some minerals in the diet are compensated by feeding on a few species with a high mineral content, such as the stems of Hypselodelphis violacea and particularly the petioles of Musanga cecropioides which contain $13380 \times 10^{-6}$ of chlorides. A similar example of adaptation to mineral nutrition is presented by Oates (1974 and this volume): a Colobus monkey obtained most of its sodium from Hydrocotyle ranunculoides, a plant occurring only in a swamp. The situation at Gombe seems quite similar. The composition of the earth samples ingested by the chimpanzees (Table VIII) differs only in the larger amounts of calcium and potassium.

The most likely function of eating clay and other phyllitous material is that it acts as an adsorbant of certain components of the stomach content such as tannins (C. M. Hladik, 1977 and this volume).

TABLE VII

Mineral content of some food samples eaten by the chimpanzee, Pan troglodytes troglodytes, in Gabon

\begin{tabular}{lrrr}
\hline & \multicolumn{1}{c}{$\mathrm{P}$} & $\mathrm{Ca}$ & $\mathrm{K}$ \\
\cline { 2 - 4 } & & & \\
Baphia leptobotrys, young leaves & 1990 & 2660 & 11790 \\
mature leaves & 2510 & 3690 & 16140 \\
Hypselodelphis violacea, stems & 990 & 2180 & 13790 \\
Nauclea diderrichii, fruits & 1090 & 2680 & 9650 \\
Musanga cecropioides, petioles of leaves & 2620 & 23970 & 54440 \\
\hline
\end{tabular}

The proportions of the different elements are in $10^{-6}$ (millionth of the dry weight).
TABLE VIII

Minerat content of samples of the earth eaton by the chimpanze, Pan troglodytes schweinliurthii, al Combe (Tanzania), collected by R. W. Wrangham

\begin{tabular}{lrrrrrrr}
\hline & $\mathrm{Ca}$ & $\mathrm{Mg}$ & $\mathrm{K}$ & $\mathrm{Na}$ & $\mathrm{Zn}$ & $\mathrm{Mn}$ & $\mathrm{Cu}$ \\
\hline $\begin{array}{l}\text { Termite mound of Macrotermes bellicosus } \\
\text { sample RW 1 }\end{array}$ & 600 & 600 & 5490 & 210 & 23 & 137 & 24 \\
sample RW 2 & 580 & 4200 & 4580 & 130 & 20 & 96 & 19 \\
\hline
\end{tabular}

The proportions of the different elements are in $10^{-6}$ (millionth of the dry weight).

\subsection{Secondary Compounds}

Tannins, alkaloids, saponines, terpenes and other secondary compounds are found in small quantities in many plant species and in large amounts in a few species. Where they are very abundant, some parts of the plant may be toxic and inedible.

Chimpanzees, like many other primates, are unable to detoxify substances by a fermentation preceding absorption and might be poisoned if the toxic substance is ingested. Thirty-eight foods eaten by the chimpanzees in Gabon were tested for alkaloids with Mayer and Dragendorff reagents. Testing was restricted to the foods (leaves and seeds) in which alkaloids were likely to occur. Similar tests were also carried out on a sample of 382 plant species collected at random in the rain forest of Ipassa where the chimpanzees have been observed (A. Hladik, 1977). In both samples, around $15 \%$ of species gave positive results indicating that the chimpanzees showed little selection against plants containing alkaloids. The main conclusion is that the alkaloids, in most of the plants in which they occur, are not toxic or not concentrated enough to be toxic. By contrast, a few species with a high alkaloid content such as the fruit of Picralima nitida (Apocynaceae) are not eaten by the chimpanzees.

Saponines, steroids and terpenes were found by Bouquet $(1972,1975)$ in a few species of the Congo rain forest, which also occur in Gabon and are eaten by the chimpanzees; but only tannins occur frequently in the leaves and bark of many species and are likely to interact with feeding behaviour (see discussion about leaf-monkeys, Hladik, this volume). In the bananas eaten by the chimpanzees at Gombe (and also frequently eaten in the old plantations in Gabon) some 3,4 dihydroxyphenylalanine (Waalkes et al., 1958) may be concentrated in the skin $\left(700 \times 10^{-6}\right)$ which is chewed with the pulp without any apparent effect. 


\section{CONCLUSION}

The study suggested that food choice in the chimpanzees was affected by variation in the levels of specific nutrients in different foods rather than by variation in secondary compounds. Several points supported this view. When the chimpanzees did not appear to be maximizing their energy return they compensated for deficiencies in the qualitative composition of their diet by ingesting species yielding specific nutrients. For example, they ate the tiny leaf buds of Baphia leptobotrys, weighing $0.05 \mathrm{~g}$ each and the rate of ingestion when feeding on these parts was evidently slow. This item is of great importance for it provides certain amino acids. Similarly, when the chimpanzees ate the petioles of Musanga cecropioides, which yield mostly fibre as a primary component, this helped to balance the mineral content of the diet.

The feeding strategy of the chimpanzee appears to be based on food resources that yield the maximum amount of nutrients. Such resources are generally widely dispersed and may also vary in temporal distribution from year to year. This explains the exceptional size of the range of the chimpanzee and its large "supplying area", compared to that of the other frugivorous primate species (Wrangham, this volume; Hladik, 1975). The feeding strategy of Presbytis senex (Hladik, this volume) is exactly the contrary of that of Pan troglodytes, with the utilization of common food sources associated with low costs in ranging and feeding movements and with low return in energy.

Feeding behaviour is conditioned by the long term response to the nutrients (see Hladik et al., 1971a; Casimir, 1975; Hladik, this volume); but the chimpanzees selection of food must necessarily be based on the immediate effects of the soluble substances detected by taste. This is the only way to increase the efficiency of foraging and gathering in an animal looking for food species dispersed over a wide range. There is no evidence that all the important nutrients can be detected by taste but the secondary compounds can be associated with the long term response and provoke an immediate effect; this might be the reason why some substances (see Section 5.4) which have no obvious effect on nutrition are selected.

\section{SUMMARY}

1, 2. A field study of one year (1971-72) and three months (1975) was carried out on a population of chimpanzees reintroduced to the rain forest of I passa, near Makokot, Galoon. Quantitative data on the food ingested were collected. Results of this study are compared with data collected by R. W. Wrangham in the Gombe National Park, Tanzania. The number of plant species is greater in Gabon than at Gombe and the varicly of food plants eaten is also greater.

3. In Gabon, as at Gombe, chimpanzees fed more on fruits in the first-half of the day and more on leaves in the second-half. During the rainy scason, a marked peak in leaf eating occurred in the last two hours of activity.

Small differences in the feeding techniques and food choice appear between the chimpanzees in Gabon and at Gombe. "Fishing" concerns mainly termites at Gombe and ants in Gabon. Macrotermes are eaten at Gombe, not in Gabon. Bark is utilized as a fibre complement with animal food in Gabon, while at Gombe, leaves play this role.

4. Seasonal changes in diet were related to plant phenology and, as at Gombe, there are important differences between years. Ranging patterns are partly related to plant distributions (data from Gabon not sufficient for comparison).

The average annual food intake (fresh weight) was $68 \%$ fruits, $28 \%$ leaves and barks and stems, $4 \%$ animal food.

5. The composition of the food specimens collected in Gabon, show that the feeding strategy of the chimpanzee is based on the utilization of the dispersed resources yielding the maximum amount of nutrients. The low protein content of fruits is compensated for by the high content of young leaves. Insects are selected for specific amino acids.

Minerals are mostly supplied by different food plants and geophagy is not an adaptation to dietetic balancing. The earth ingested may serve to adsorb tannins or other secondary compounds.

Some rare plants showing high levels of toxic compounds are avoided by chimpanzees. Although "secondary compounds" are found in small amounts in many food plants, there is no evidence that chimpanzees select plant species where these are absent.

\section{ACKNOWLEDGEMENTS}

The project related to the chimpanzees in Gabon, was initiated by Professor P. P. Grassé, in 1963. Many other scientists of the CNRS co-operated for its continuation, at the Ipassa field station. Annette Hladik developed the botanical researches and the tests for alkaloids presented in this paper. R. W. Wrangham collected the food samples from Gombe, for which analytical data are presented. 